$p$-ISSN 1693-9484, $e$-ISSN : 2621-8313

Majalah Ilmiah Bahari Jogja (MIBJ)

Vol. 18 No. 1, Februari $2020 \quad(153-165)$

DOI : 10.33489/mibj.v18i1.234

(C) 2020 Sekolah Tinggi Maritim Yogyakarta

\title{
Pengembangan Model Bisnis Tentang Telekomunikasi di Perusahaan Berdasarkan Perspektif Pelanggan
}

\author{
Zoelly's Fix Nurfadholi ${ }^{*}$ \\ ${ }^{1}$ Prodi Manajemen Transportasi Laut, Sekolah Tinggi Maritim Yogyakarta, Jl. Magelang \\ KM 4.4, Yogyakarta 55284, Indonesia \\ * Corresponding Author. E-mail : zoellys.nurfadholi@ gmail.com. Telp : +628562700010
}

\begin{abstract}
Abstrak
Telekomunikasi sudah menjadi kebutuhan dalam setiap aktivitas. Berdasarkan hasil publikasi Badan Pusat Statistik (2018) jumlah pelanggan telepon seluler di Indonesia mencapai 319,4 juta. Berdasarkan angka tersebut terdapat potensi pasar yang besar karena dapat diasumsikan bahwa setiap pelanggan membutuhkan setidaknya satu buah nomor telepon, dan setiap nomor tersebut dibutuhkan biaya-biaya agar dapat digunakan untuk telekomunikasi seperti tagihan bulanan bagi pelanggan nomor pascabayar dan pulsa bagi pelanggan nomor prabayar. Kebutuhan telekomunikasi tidak hanya terjadi di tingkat individu namun juga terjadi di lingkungan organisasi seperti pada perusahaan yang nantinya akan dijadikan sebagai pasar sasaran utama dalam model bisnis. Potensi pasar yang besar memunculkan ide untuk membuat suatu konsep bisnis yang fokus pada segmen pelaggan perusahaan yang mampu memberikan kemudahan, keamanan, fleksibel, dan transparan sehingga dapat mempermudah aktivitas bisnis perusahaan dan mengurangi risiko kerugian akibat tunjangan komunikasi yang disalahgunakan.
\end{abstract}

Kata Kunci: model bisnis, perusahaan, telekomunikasi, prabayar, pascabayar

\begin{abstract}
Telecommunications has become a necessity in every activity. Based on the results of the publication of the Central Statistics Agency (2018) the number of cellular telephone subscribers in Indonesia reached 319.4 million. Based on this number there is a large market potential because it can be assumed that each customer requires at least one telephone number, and each number is required to be used for telecommunications costs such as monthly bills for postpaid number customers and phone credit for prepaid number customers. Telecommunications needs not only occur at the individual level but also in an organizational environment such as the company which will later be used as the main target market in the business model. The large market potential gave rise to the idea to create a business concept that focuses on the company's customer segment that is able to provide convenience, security, flexibility, and transparency so as to facilitate the company's business activities and reduce the risk of loss due to misused communication benefits.
\end{abstract}

Keywords: business model, company, telecomunication, prepaid, postpaid 


\section{PENDAHULUAN}

Salah satu dampak perkembangan teknologi pada industri telekomunikasi yang sedang mengalami perkembangan pesat adalah telepon tanpa kabel. Menurut publikasi Badan Pusat Statistik (2018) tentang Statistik Telekomunikasi Indonesia menyatakan bahwa perkembangan jumlah pelanggan telepon tanpa kabel di Indonesia terus mengalami peningkatkan yang cukup signifikan dari tahun ke tahun. Berdasarkan publikasi tersebut, pada tahun 2018 tercatat sebanyak 319,4 juta pelanggan telepon seluler di Indonesia. Menurut Badan Pusat Statistik (2019), jumlah angka tersebut melebihi jumlah populasi penduduk Indonesia pada tahun tersebut yaitu sebesar 269 juta jiwa. Berdasarkan angka tersebut terdapat potensi pasar yang besar karena dapat diasumsikan bahwa setiap telepon tanpa kabel membutuhkan setidaknya satu buah nomor telepon, padahal setiap nomor tersebut dibutuhkan biaya-biaya agar dapat digunakan untuk telekomunikasi seperti tagihan bulanan bagi pelanggan nomor pascabayar dan pulsa bagi pelanggan nomor prabayar.

Kebutuhan telekomunikasi tidak hanya terjadi di tingkat individu namun juga terjadi di lingkungan organisasi seperti pada perusahaan yang nantinya akan dijadikan sebagai pasar sasaran utama dalam model bisnis. Telekomunikasi di perusahaan sudah menjadi bagian dari akvititas utama sehari-hari sehingga kebutuhan akan telekomunikasi mutlak diperlukan agar perusahaan tersebut mampu bersaing di era saat ini

Perusahaan memberikan tunjangan komunikasi pra dan pascabayar yang beragam kepada pegawai setiap bulannya. Tunjangan komunikasi yang diberikan untuk pegawai dalam bentuk uang dapat disalahgunakan pemanfaatannya dan sulit dilakukan kontrol. Sedangkan pemberian tunjangan komunikasi dengan mengisikan pulsa prabayar cukup merepotkan perusahaan karena nomor yang diisi harus diinputkan secara manual setiap transaksi dan dapat menimbulkan kesalahan pengisian. Disamping itu pemberian tunjangan yang dilakukan menggunakan pascabayar berisiko melebihi anggaran. Selain itu sistem perbankan seperti autodebet dan internet banking memiliki kelemahan sehingga tidak dapat menyelesaikan permasalahan tunjangan komunikasi yang dihadapi perusahaan.

Disisi lain potensi pasar yang besar dan belum tersedianya fasilitas yang mampu mengatasi permasalahan yaitu adanya potensi bisnis penjualan pulsa yang besar dengan pembayaran secara kredit dan belum tersedianya dokumen yang komprehensif untuk menyusun model bisnis tersebut menjadikan suatu peluang bisnis yang menarik untuk dijalankan. Dari permasalahan tersebut memunculkan ide untuk membuat suatu konsep bisnis penyedia pengelolaan tunjangan komunikasi perusahaan yang mampu memberikan kemudahan, keamanan, fleksibel, dan transparan sehingga dapat mempermudah aktivitas bisnis perusahaan dan mengurangi risiko kerugian akibat tunjangan komunikasi yang disalahgunakan. 


\section{KAJIAN LITERATUR}

\section{Kanvas Model Bisnis}

Menurut Pigneur dan Osterwalder (2010) kanvas model bisnis adalah bahasa yang digunakan bersama untuk menggambarkan, memvisualisasikan, menilai dan merubah model bisnis yang sedang dibahas. Penggunaan kanvas, maka model bisnis yang ada dapat dengan mudah didiskusikan, serta dirubah selama diskusi sesuai dengan fakta dan pertimbangan yang ada. Kanvas ini terdiri dari sembilan komponen atau kotak-kotak yang juga disebut nine building blocks seperti pada Gambar 1.

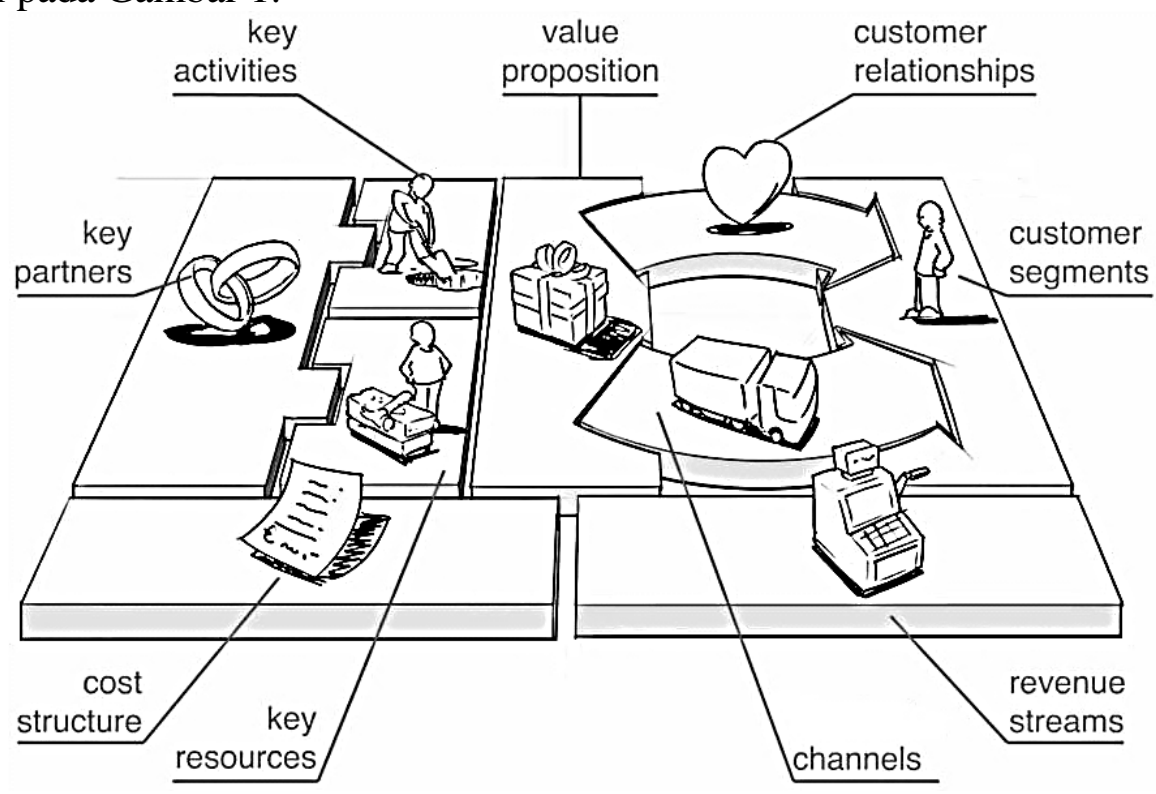

Gambar 1: Kanvas Model Bisnis

Sumber: Pigneur dan Osterwalder, 2010

\section{Segmen Pelanggan (Customer Segments)}

Menurut Swastha dan Handoko (1997) segmentasi pasar (pelanggan) adalah sebagai kegiatan mengelompokan pasar atau market yang bersifat heterogen kedalam satuan pasar yang bersifat homogen yang dijadikan sasaran penjualan yang akan dicapai dengan marketing mix. Menurut Pride dan Ferrel (1995) segmentasi pasar (pelanggan) adalah suatu proses membagi pasar ke dalam segmen-segmen pelanggan potensial dengan kesamaan karakteristik yang menunjukkan adanya kesamaan perilaku pembeli.

\section{Proposisi Nilai (Value Propositions)}

Menurut Pigneur dan Osterwalder (2010) value proposition atau proposisi nilai adalah suatu nilai atau manfaat yang ditawarkan oleh perusahaan kepada segmen pelanggan yang dilayani. Manfaat ini terwujud dalam bentuk sekumpulan produk atau jasa. Di mata pelanggan, proposisi nilai ini adalah sebagai solusi atau jawaban atas apa yang dibutuhkan, atau pemecahan dari masalah yang dihadapi oleh pelanggan. 


\section{Saluran (Channels)}

Menurut Nitisemito dalam Tamuntuan (2013) saluran distribusi adalah lembaga penyalur yang mempunyai kegiatan untuk mengirimkan barang atau jasa dari produsen ke konsumen. Sedangkan menurut Kolter dalam Tamuntuan (2013) saluran distribusi adalah sekelompok perusahaan atau perseorangan yang membantu memindahkan hak pemilikan produk atau jasa dari produsen ke konsumen. Sehingga dapat disimpulkan bahwa saluran distribusi adalah bagaimana perusahaan berkomunikasi dan mencapai pelanggannya untuk memberikan proposisi nilai dalam model bisnis kanvas yang mendeskripsikan aktivitas komunikasi, distribusi dan jalur penjualan merupakan antar muka bagi perusahaan dan pelanggannya.

\section{Hubungan Pelanggan (Customer Relationships)}

Menurut Pigneur dan Osterwalder (2010) terdapat beberapa bentuk dalam hubungan pelanggan, antara lain asisten personal, asisten personal terdedikasi, self-service, dan layanan terotomatisasi. Hubungan pelanggan dipilih dan ditentukan tentunya disesuaikan dengan perusahaan seperti apa. Asisten personal digunakan misalkan digunakan ketika membentuhkan pelayanan yang baik kepada pelanggan. Namun apabila pelanggan tersebut spesial sehingga membutuhkan layanan khusus, maka dibutuhkan asisten personal yang terdedikasi karena hubungan ini ingin dibangun dalam jangka waktu yang lama dan tidak berganti-ganti. Dalam satu kondisi tertentu, seperti di supermarket misalkan hubungan self-service justru menjadi pilihan utama karena pelanggan merasa lebih nyaman apabila melayani sendiri. Namun apabila hubungan self-service membutuhkan kemudahan-kemudahan kepada pelanggan maka pilihan layanan terotomatasisasi dapat menjadi solusi.

\section{Arus Pendapatan (Revenue Streams)}

Pendapatan merepresentasikan bagaimana perusahaan menghasilkan uang dari segmen pelanggan yang dilayaninya. Perusahaan harus dapat memutuskan harga berapa pelanggannya mau membayar untuk produk yang ditawarkan. Selain itu, perusahaan juga harus dapat mendefinisikan bagaimana cara untuk menghasilkan uang tersebut. Menurut Pigneur dan Osterwalder (2010) terdapat dua tipe pendapatan antara lain yaitu pendapatan dalam satu waktu dan pendapatan yang didapatkan berulang dan terus menerus. Dari dua tipe tersebut diterapkan sumber pendapatan yang terus menerus setiap bulannya dari pelanggan melalui sebuah kontrak kerja sama yang mengharuskan perusahaan sebagai pelanggan membayarkan atas produk pulsa elektrik yang telah dibeli.

\section{Sumber Daya Utama (Key Resources)}

Menurut Pigneur dan Osterwalder (2010) sumber daya utama mendefinisikan aset atau sumber daya yang paling penting, agar model bisnis yang sudah ditentukan dapat berjalan. Sumber daya tersebut memungkinkan perusahaan untuk membuat dan menawarkan proposisi nilai, mencapai pasar yang ada, menjaga hubungan kepada segmen pelanggan dan mendapatkan penghasilan. 
Sumber daya utama dapat dimiliki oleh perusahaan, sewa dari tempat lain ataupun didapatkan dari rekanan inti perusahaan.

\section{Aktivitas Kunci (Key Activities)}

Menurut Pigneur dan Osterwalder (2010) pada building blocks aktivitas kunci, perusahaan mendefinisikan aktivitas kunci yang harus dilakukan agar model bisnis yang sudah ditetapkan dapat berjalan. Aktivitas-aktivitas tersebut dibutuhkan untuk membuat dan menawarkan proposisi nilai, mencapai pasar yang ada, menjaga hubungan kepada segmen pelanggan dan mendapatkan penghasilan.

\section{Kemitraan Utama (Key Partners)}

Kemintraan pada intinya dikenal dengan istilah gotong royong atau kerjasama antar pihak, baik individu ataupun kelompok. Menurut Notoatmodjo (2003), kemitraan adalah suatu kerja sama formal antara individu atau kelompok atau organisasi untuk mencapai tujuan tertentu. Di dalam nine building blocks kemitraan utama mendefinisikan rekanan maupun pemasok yang paling berpengaruh pada perusahaan agar perusahaan dapat menjalankan model bisnisnya dengan baik. Perusahaan membuat aliansi untuk optimalisasi model bisnis, mengurangi risiko atau untuk mendapatkan sumber daya.

\section{Struktur Biaya (Cost Structure)}

Menurut Pigneur dan Osterwalder (2010), terdapat dua pendekatan dari struktur biaya ini, yaitu biaya (cost-driven) yang mengedepankan penghematan dan nilai (value-driven) dengan mengutamakan kualitas. Nine building blocks mendefinisikan biaya-biaya yang paling penting, yang dibutuhkan untuk menjalankan model bisnis yang telah ditentukan. Membuat dan menawarkan proposisi nilai, mencapai pasar yang ada, menjaga hubungan kepada segmen pelanggan dan mendapatkan penghasilan, semua membutuhkan biaya. Biayabiaya ini akan lebih mudah didefinisikan jika sumber daya kunci dan aktivitas kunci terlebih dahulu didefiniskan. Secara natural, biaya-biaya harus ditekan guna mencapai keunggulan kompetitif. Namun terkadang, rendahnya biaya ini lebih penting bagi satu jenis model bisnis, ketimbang model bisnis lainnya.

\section{METODE PENELITIAN}

\section{Level Analisis}

Level analisis penelitian ini dilakukan pada level organisasi karena perusahaan yang merupakan segmen pelanggan yang disasar, sehingga menjadi subjek utama dalam penelitian ini. Pada penelitian ini disusun model bisnis yang dianalisis berdasarkan data-data yang ada.

\section{Sumber Data}

Dalam melakukan penelitian diperlukan berbagai macam informasi dan data, menurut Cooper dan Schindler (2011) sumber informasi dibagi menjadi tiga tingkatan yaitu sumber primer, sumber sekunder dan sumber tersier.

Dalam penyusunan model bisnis ini data primer akan dikumpulkan dengan wawancara, Focus Group Discussion (FGD) dan observasi. Data sekunder berasal 
dari buku teks, jurnal dan artikel sedangkan data tertier berasal dari internet untuk melengkapi data-data yang tidak tersedia dari sumber primer dan sekunder.

\section{Metode Pengumpulan Data}

1. Wawancara

Wawancara dilakukan dengan beberapa manajemen, pemilik dan karyawan perusahaan di Yogyakarta dan para pemangku kepentingan lainnya seperti bank dan operator telekomunkasi untuk mendapatkan informasi tentang hal-hal yang berkaitan dengan telekomunikasi sebagai bahan prastudi, analisis dan informasi awal yang akan digunakan untuk bahan dikusi dalam Focus Group Discussion.

\section{Focus Group Discussion (FGD)}

FGD dilakukan dengan tujuh Partisipan yaitu pengusaha, pihak manajemen dan karyawan perusahaan yang sebelumnya telah dilakukan wawancara. Partisipan FGD ditentukan berdasarkan perusahaan dengan industri dan ukuran perusahaan yang beragam sesuai dengan kriteria Usaha Kecil Menengah (UKM) menurut Badan Pusat Statistik (BPS), di daerah Yogyakarta yang berskala lokal, nasional dan multinasional dan menggunakan telekomunikasi untuk aktivitas bisnisnya. FGD dilakukan untuk mendapatkan gambaran secara mendalam mengenai permasalahan telekomunikasi yang digunakan perusahaan dan untuk mengetahui prospek bisnis dengan menghitung besarnya rata-rata pengeluaran perusahaan yang digunakan untuk telekomunikasi.

3. Observasi

Metode observasi dilakukan dengan menginvestigasi secara langsung untuk mendapatkan informasi terkait, yaitu dengan melakukan pengamatan dan pencarian di internet, menjadi nasabah bank dan mencoba melakukan beberapa transaksi, menjadi pembeli dan client di beberapa pesaing bisnis pulsa yang sudah ada, dan menjadi karyawan pada sebuah perusahaan penyedia pulsa di Yogyakarta.

\section{HASIL DAN PEMBAHASAN}

Dari hasil wawancara yang telah dilakukan sebelumnya didapatkan permasalahan utama perihal telekomunikasi yang dihadapi oleh perusahaan terkait pascabayar dan prabayar terdapat beberapa hal antara lain kontrol pemakaian, kepraktisan, risiko, abonemen atau minimal pemakaian, dan tarif atau harga. Hasil wawancara tersebut kemudian dijadikan bahan dan tema yang akan dibahas satu persatu dalam FGD. Berikut beberapa pertanyaan yang diajukan kepada Partisipan:

1. "Bagaimana layanan telekomunikasi yang digunakan perusahaan saat ini?"

Dari tujuh Partisipan FGD, saat ini sebanyak 70 persen menggunakan layanan pascabayar, dan sisanya prabayar untuk keperluan telekomunikasi di perusahaannya baik dalam bentuk fixed line ataupun mobile. Semua 
Partisipan membenarkan bahwa perusahaan mereka kurang lebih juga mengalami permasalahan telekomunikasi yang sama.

2. "Bagaimana pendapat Anda tentang permasalahan telekomunikasi tersebut?"

a. Kontrol pemakaian

Sulitnya mengontrol pemakaian membuat terkadang membuat tagihan yang dapat membengkak. Menurut hasil diskusi permasalahan ini dapat diatasi dengan melakukan pembatasan maksimal pemakaian namun pembatasan maksimal pemakaian dirasa kurang flesibel mana kala perusahaan kadang pada posisi low session dan high session. Hal ini berbeda dengan layanan prabayar yang dapat membatasi penggunaannya karena pelanggan bayar terlebih dahulu sebelum memakai. Dengan begitu pelanggan bisa membatasi, namun masih bisa flesibel sehingga budget telekomunikasi pada setiap bulannya dapat lebih terkontrol.

b. Kepraktisan

Alasan utama menggunakan pascabayar menurut Partisipan karena kepraktisannya. Pelanggan tidak direpotkan dengan hal teknis pengisian pulsa seperti prabayar dan pembayaran karena dibayarkan diakhir dan terdapat fasilitas autodebet perbankan yang dapat menjadi solusi pembayaran tiap bulannya. Lain hal dengan prabayar yang repot dalam pengisiannya karena tidak difasilitasi oleh autodebet perbankan dan harus melakukan pengisian dengan cara memasukan nomor atau nominal setiap kali pengisian, hal ini cukup merepotkan dapat menyebabkan terjadinya kesalahan penginputan, semakin banyak frekuensi pengisian atau nomor yang diisi maka semakin banyak kemungkinan kesalahan terjadi.

c. Risiko

Menurut Partisipan, menggunakan pascabayar memang tidak semudah pelanggan prabayar. Karena keterikatan pelanggan dengan operator, pelanggan yang kehilangan kartu atau ponselnya diwajibkan untuk melapor pada operator yang bersangkutan. Karena jika tidak kartu atau ponsel berpindah tangan bisa saja digunakan oleh orang lain tanpa sepengetahuan penggunanya dan hasilnya tagihan penggunaan kartu tetap saja akan ditagih ke pendaftar. Belum lagi apabila pembayaran tagihan menggunakan autodebet, berisiko terjadi gagal bayar yang mengakibatkan terkena denda karena jumlah tagihan melebihi sisa saldo yang ada. Berbeda dengan prabayar yang tidak memiliki keterikatan sehingga mudah pengurusannya apabila berpindah tangan. Jika kartu prabayar hilang, pelanggan tidak memiliki risiko lainnya kecuali kerugian pulsa yang ada didalamnya kartu tersebut. Disisi lain prabayar berisiko ketika salah dalam pengisian pulsa karena salah nomor atau gagal isi sehingga memungkinkan terjadinya SIM (Subscriber Identity Module) card tidak dapat dipakai lagi karena expired.

d. Abonemen atau Pemakaian Minimal

Menurut kesaksian Partisipan, ada beberapa operator memang meniadakan biaya abonemen, tetapi kenyataannya operator menetapkan batas minimal 
pelanggan atau pemakaian pada setiap bulannya untuk pelanggan kartu pascabayar. Lain hal dengan kartu prabayar dengan mengisi ulang pulsa sesuai kebutuhan, maka kartu prabayar sudah bisa aktif dan masih memiliki masa tenggang.

e. Tarif atau Harga

Menurut Partisipan saat ini para operator lebih banyak memperhatikan kartu prabayar dengan memberikan banyak promo-promo yang ditawarkan khusus kartu prabayar, seperti bonus telepon, pesan, hingga data. Disisi lain tarifnya pun beragam sehingga dapat menyesuikan kebutuhan perusahaan untuk telepon, sms, data atau ketiganya. Pascabayar yang minim promo, tarifnya flat (mahal), bahkan hampir tidak tersentuh program bonus, belum lagi ditambah pajak.

3. "Bagaimana perusahaan Anda dalam menentukan anggaran telekomunikasi?"

Dari hasil diskusi tersebut para Partisipan menjelaskan tentang anggaran pengeluaran perusahaan untuk telekomunikasi. Anggaran yang dikeluarkan perusahaan sangat bervariasi bergantung pada kebutuhan perusahaan tersebut pada saat kondisi low session ataupun high session. Anggaran perusahaan dapat naik turun rata-rata hingga 10 persen pada kondisi tersebut. Ukuran perusahaan dan jumlah karyawan tidak menentukan besar kecilnya anggaran pengeluaran telekomunikasi sehingga didapatkan empat kategori pengeluaran perusahaan perbulan untuk telekomunikasi antara lain kurang dari 199.000 rupiah untuk perusahaan yang tidak bergantung telekomunikasi untuk aktivitas bisnisnya, antara 200.000 hingga 1.999.999 rupiah untuk perusahaan yang sedang dalam penggunaan telekomunikasi, kemudian 2.000.000 hingga 4.999.999 rupiah adalah perusahaan yang tingkat penggunaan telekomunikasinya tinggi, dan terakhir diatas 5.000.000 rupiah untuk perusahaan yang menggunakan telekomunikasi sebagai channel utama dalam berhubungan dengan pelanggan dan mitra.

4. "Bagaimana harapan Anda tentang layanan telekomunikasi untuk perusahaan kedepan?"

Harapan utama Partisipan FGD tentang layanan telekomunikasi untuk perusahaan kedepan adalah layanan yang lebih efisien atau murah, lancar, aman, dan mudah. Dari harapan tersebut disampaikan ide bisnis tentang layanan telekomunikasi yang lebih efisien dan murah dengan tarif prabayar, dengan fasilitas pascabayar seperti pembayaran diakhir, dan mudah yaitu menggunakan website sebagai dashboard. Partisipan memberikan saran layanan substitusi untuk telekomunikasi yang murah dengan teknologi internet seperti aplikasi Skype, Whatsapp, Telegram, dan lainnya namun Partisipan tetap memilih menggunakan layanan prabayar agar lebih flesibel. Dari ide bisnis dan saran tersebut 100 persen Partisipan sepakat dan setuju agar dijadikan ide bisnis tersebut direalisasikan. 


\section{Peta Empati}

Menurut Pigneur dan Osterwalder (2010) untuk memudahkan dalam mendesain model bisnis dan mendapatkan gambaran yang jelas dari perspektif pelanggan maka data-data yang dan kesimpulan hasil wawancara dan FGD yang telah didapat divisualisasikan kedalam peta empati. Data-data tersebut dalam peta empati dibagi menjadi enam bagian yang disusun menggunakan pertanyaan dengan jawaban dari perspektif pelangan. Pertanyaan dalam peta empati antara lain See?, Hear?, Think and Feel?, Say and Do?, Pain?, Gain?. Berikut peta empati dapat dlihat pada Gambar 2.

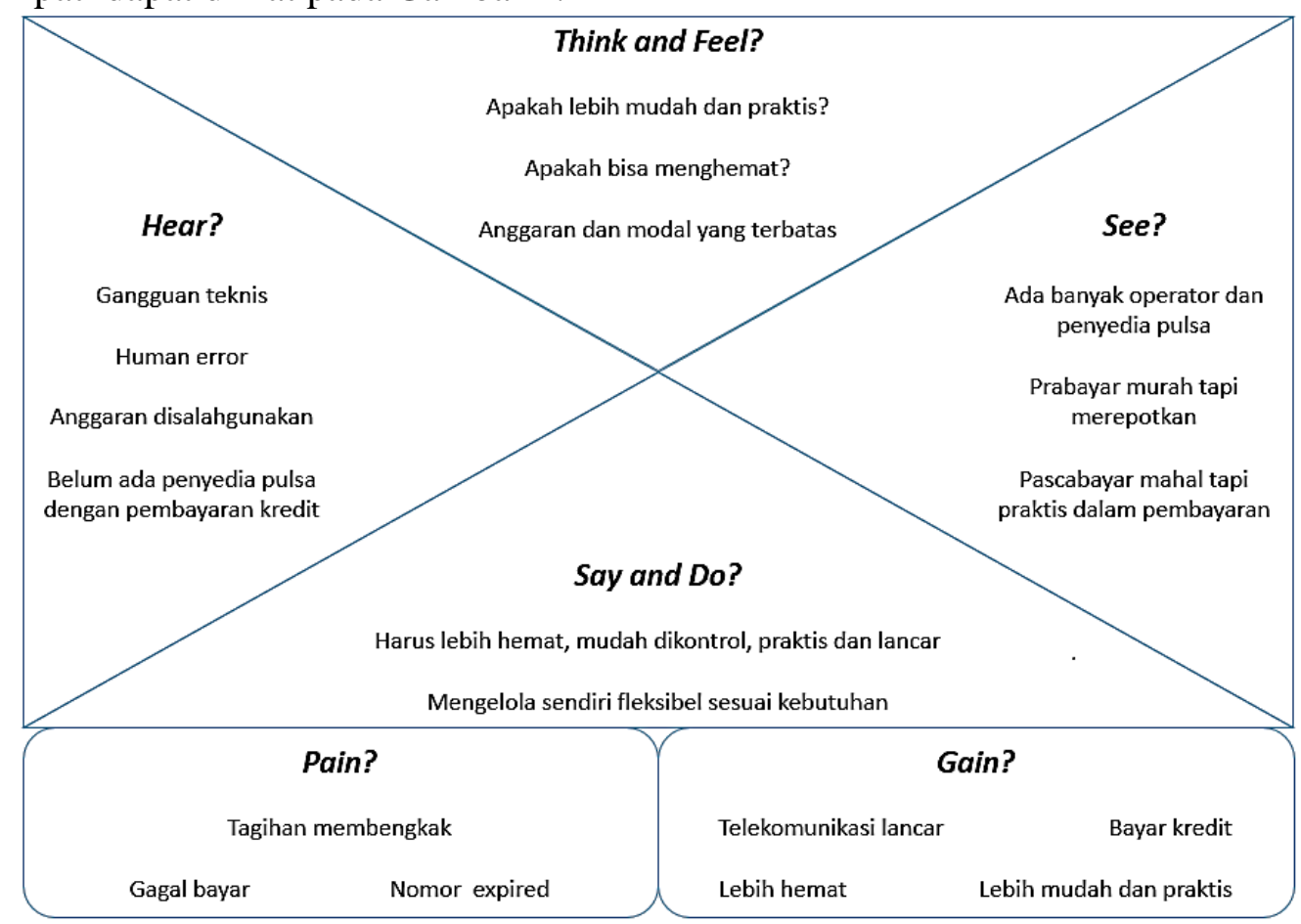

Gambar 2: Peta Empati

\section{Model Bisnis}

\section{Segmen Pelanggan (Customer Segments)}

Calon pelanggan fokus kepada perusahaan sehingga segmen pelanggan masuk dalam kategori segmented. Penentuan perusahaan sebagai target pasar didasarkan atas adanya permasalahan yang terjadi dalam perusahaan terkait dengan kebutuhan telekomunikasi.

\section{Proposisi Nilai (Value Propositions)}

Proposisi nilai yang ditawarkan kepada customer dalam hal ini perusahaan adalah layanan pulsa prabayar dengan sistem pembayaran pascabayar (kredit) sehingga menjadi lebih flexibel bagi perusahaan. Layanan pembayaran secara pascabayar merupakan fasilitas yang diberikan kepada perusahaan yang berkualifikasi atau memenuhi syarat untuk diberikan kredit. Manfaat lain yang 
diberikan adalah berupa fasilitas dashboard yang dapat diakses kapanpun dan dimanapun melalui komputer ataupun gadget.

\section{Saluran (Channels)}

Saluran utama yang digunakan adalah website yang mengutamakan penggunaan teknologi informasi untuk menyalurkan proposisi nilai kepada pelanggan karena dinilai produk yang ditawarkan berupa pulsa elektrik yang akan lebih efisien dan efektif apabila menggunakan media elektronik juga sebagai salurannya. Disamping itu dilakukan direct marketing karena sasaran pelanggan perusahaan yang membutuhkan penawaran langsung.

\section{Hubungan Pelanggan (Customer Relationships)}

Hubungan seperti apa yang sebaiknya dilakukan oleh perusahaan dan pelanggan sebagai perusahaan dan pelanggannya yaitu perusahaan haruslah tercapai suatu hubungan yang saling menguntungkan. Kepercayaan sangat dibutuhkan dalam menjalin hubungan, namun hal tersebut belum cukup karena proposisi nilai yang ditawarkan adalah pulsa elektrik prabayar dengan sistem pembayaran dilakukan secara kredit, hal tersebut dibutuhkan landasan hukum yang kuat agar dapat meminimalkan risiko gagal bayar. Sistem yang cocok digunakan dalam meminimalkan risiko gagal bayar adalah menggunakan sistem kontrak karena dengan kontrak maka dapat mengikat para pihak dengan suatu kesepakatan atau perjanjian tertentu yang memiliki kekuatan hukum dan dilindungi oleh negara. Bagi perusahaan, dengan kontrak dapat memberikan kepastian kerja sama dari layanan yang diberikan sehingga operasional dan keuangan perusahaan menjadi lebih terjamin. Disamping itu asisten personal, telepon dan sms juga dilakukan untuk menjaga hubungan kerja sama agar selalu terjalin baik.

\section{Arus Pendapatan (Revenue Streams)}

Sumber pendapatan yang terus menerus setiap bulannya dari pelanggan melalui sebuah kontrak kerja sama yang mengharuskan perusahaan sebagai pelanggan membayarkan atas produk yang telah dibeli. Adapun arus pendapatan utama berasal dari margin penjualan atas produk berupa pulsa elektrik, dan untuk pendapatan sampingan dapat berasal dari denda kredit yang telat dibayarkan.

\section{Sumber Daya Utama (Key Resources)}

Salah satu yang menjadi sumber daya utama adalah banyaknya mitra yang bekerja sama. Dengan adanya banyak mitra maka akan lebih mudah memperoleh data dan informasi yang dapat menguntungkan usaha, disamping itu peluang kerja sama juga semakin terbuka. Informasi, di dalamnya termasuk data, memiliki nilai dari apa yang diwakilinya, yang termasuk dalam sumber daya informasi. Sumber daya informasi diperlukan untuk mengelola sumber daya fisik. Itu sangat penting bagi para manajer maupun para pengguna informasi untuk mengetahui bagaimana suatu perusahaan mengelola sumber datanya, sehingga memudahkan mereka untuk mendapatkan data yang diperlukan. Sumber daya utama lainnya adalah manusia. Setiap perusahaan bergantung pada manusia. Namun pada industri yang 
secara intensif bergantung pada pengetahuan, kebutuhan akan manusia yang baik sangat tinggi. Manusia merupakan salah satu aspek yang menjadi sumber daya utama, karena bergerak dibidang pulsa elektrik yang membutuhkan teknologi terkini berupa website sehingga dibutuhkan programmer yang berpengalaman. Dalam merintis suatu bisnis pulsa khususnya elektrik bukanlah hal yang sulit, hampir setiap orang dapat mempelajarinya dan dapat langsung mempraktekannya, namun bisnis pulsa elektrik yang menyasar pelanggan tertentu yaitu perusahaan dengan menawarkan proposisi nilai yang unik dibutuhkan kemampuan dan pengalaman yang lebih untuk mengelolanya. Sumber daya yang tidak kalah pentingnya adalah finansial. Kemampuan finansial yang baik maka perusahaan dapat menjalankan proyek dan membiayai pengeluaran rutin.

\section{Aktivitas Kunci (Key Activities)}

Aktivitas kunci dalam perusahaan sangat ditentukan oleh model bisnisnya. Bisnis yang bergerak dibidang penjualan pulsa elektrik sangat dipengaruhi oleh perangkat lunaknya, khususnya website yang dijadikan sebagai saluran utama untuk menghubungkan proposisi nilai ke pelanggan. Website yang baik membutuhkan pengembangan terus menerus agar selalu mengikuti perkembangan teknologi untuk mengimbangi kebutuhan dan keinginan pelanggan yang terus berkembang, sehingga target penjualan dapat tercapai sehingga research and development dan promosi merupakan salah satu aktivitas kunci yang dilakukan.

\section{Kemitraan Utama (Key Partners)}

Menurut Ditjen P2M dan PL (2004), terdapat tiga prinsip kunci yang perlu dipahami dalam membangun suatu kemitraan yaitu prinsip kesetaraan (equity), dengan prinsip ini maka setiap pihak harus merasa sama atau sejajar kedudukannya satu sama lain dalam mencapai tujuan yang disepakati. Prinsip kedua adalah keterbukaan, dengan prinsip ini setiap pihak harus memiliki keterbukaan terhadap kekurangan dan kelebihannya serta saling melengkapi satu sama lain.Prinsip yang terakhir adalah azas manfaat bersama. Setiap pihak yang telah menjalin kemitraan memperoleh manfaat dari kemitraan yang terjalin sesuai dengan kesepakatan atau kontribusi masing-masing. Kegiatan atau pekerjaan akan menjadi efisien dan efektif apabila dilakukan bersama. Beberapa mitra utama antara lain operator telekomunikasi, penyedia jasa internet, penyedia hosting, asosiasi, dan asuransi.

\section{Struktur Biaya (Cost Structure)}

Pendekatan struktur biaya yang akan digunakan lebih kepada cost-driven yaitu dengan melakukan perampingan fungsional dengan memanfaatkan teknologi sehingga dapat dilakukan otomatisasi. Namun bukan berati kualitas tidak diperhatikan, dengan penggunaan sistem yang terkomputerisasi dapat mengurangi terjadinya human error sehingga kualitas layanan akan semakin baik. Adapun biaya-biaya yang muncul berasal dari operasional, research and development, website, dan promosi. Berdasarkan sembilan komponan model bisnis tersebut maka dapat digambarkan nine building bloks model bisnis yang dapat dilihat pada Gambar 3 . 


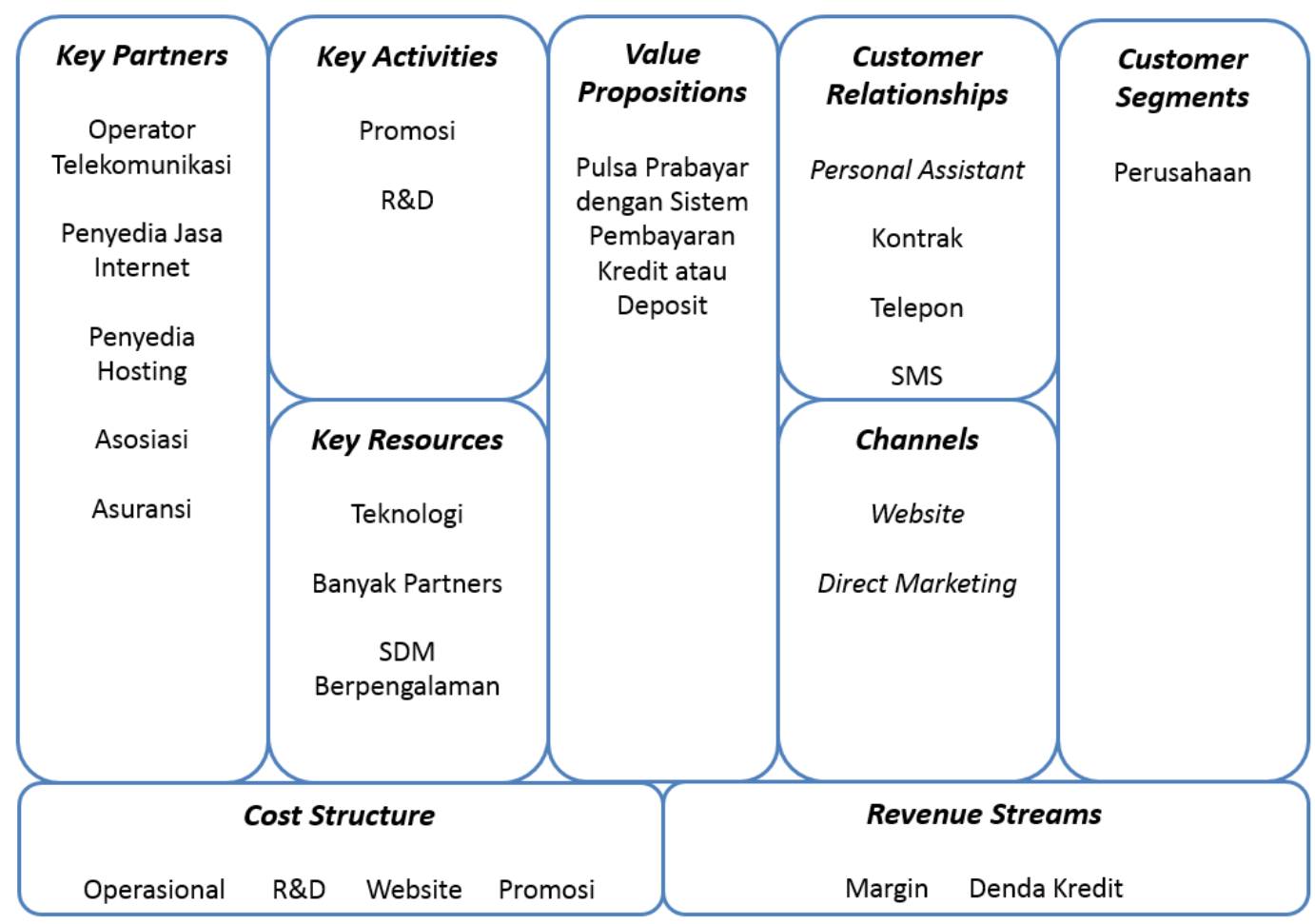

Gambar 3: Model Bisnis

\section{SIMPULAN}

Berdasarkan hasil penelitian maka dapat diambil kesimpulan antara lain sebagai berikut:

1. Pengembangan model bisnis dapat dilakukan dengan menggunakan wawancara dan diskusi dengan calon pelanggan.

2. Industri telekomunikasi memiliki potensi pasar yang sangat besar.

3. Ide bisnis dapat digali dari persoalan nyata yang terjadi lingkungan sekitar.

4. Peluang bisnis penyedia layanan telekomunikasi untuk perusahaan memiliki potensi yang besar untuk direalisasikan.

5. Model bisnis layak untuk disusun rencana bisnis komprehensif agar ide bisnis tersebut dapat direalisasikan dengan baik.

\section{DAFTAR PUSTAKA}

Badan Pusat Statistik, (2018). Statistik Telekomunikasi Indonesia. Jakarta: BPS.

Badan Pusat Statistik, (2019). Statistik Indonesia. Jakarta: BPS.

Cooper, D., R., dan Schindler, P., S., (2011). Business Research Methods 11th edition. McGraw-Hill International Edition.

Ditjen P2M dan PL, (2004). Pelatihan Manajemen P2L \& PL Terpadu Berbasis Wilayah Kabupaten / Kota Membina Kemitraan Berbasis Institusi. Jakarta: Depkes RI. 
Notoatmodjo, Soekidjo, (2003). Pendidikan dan Perilaku Kesehatan, Jakarta: Rineka Cipta.

Osterwalder, A., Pigneur, Y., (2010). Business Model Generation. John Wiles \& Sons, Inc. Hokoben, New Jersey.

Pride, W., M., dan Ferrel, O., C., (1995). Pemasaran: Teori dan Praktek Seharihari. Jakarta: Binarupa Aksara.

Swasta, B., dan Handoko, T., H., (1997). Manajemen Pemasaran: Analisa Perilaku Konsumen. Yogyakarta: BPFE.

Tamuntuan, Nisia, (2013). Analisis Saluran Distribusi Rantai Pasokan Sayur Wortel di Kelurahan Rurukan Kota Tomohon. Jurnal E MBA, Jurusan Manajemen, Fakultas Ekonomi dan Bisnis, Universitas Sam Ratulangi, Manado. 